Лариса Макарук

\title{
ФУНКЦІЮВАННЯ ДІАКРИТИЧНИХ, МАТЕМАТИЧНИХ ТА ТИПОГРАФІЧНИХ ЗНАКІВ У СУЧАСНОМУ АНГЛОМОВНОМУ МАСМЕДІЙНОМУ КОМУНІКАТИВНОМУ ПРОСТОРІ
}

Статтю присвячено дослідженню невербальних та паравербальних ресурсів, які функціонують у сучасному англомовному масмедійному комунікативному просторі. У роботі проаналізовано діакритичні, математичні та типографічні знаки як невербальні елементи, що є складниками однієї з груп, які загалом охоплюють невербальні та паравербальні компоненти, що функціонують у сучасному англомовному масмедійному комунікативному просторі. До аналізованої групи «Непіктографічні та нефотографічні елементи» входять знаки пунктуації; діакритичні знаки; типографічні й інші допоміжні знаки; цифри (числа); математичні символи; абревіатури. У цій розвідці докладно висвітлено специфіку діакритичних, математичних та типографічних знаків як інтегральних модусів масмедійного середовища.

Окреслено їх семантичні та структурні особливості, ідентифіковано функційне навантаження, обгрунтовано їх роль та призначення в сучасному англомовному масмедійному комунікативному просторі. Крім традиційного використання, діакритичним, математичним та типографічним знакам також притаманне й нетрадиційне. Установлено, що в масмедійному просторі спектр потенційних можливостей діакритичних, математичних та типографічних знаків значно ширший, що й доводить їх поліфункційність.

Діакритики поруч зі знаками пунктуації часто мають значення, яке виходить за рамки їх традиційного призначення. Такі комбінації невипадкові, це ретельно продумані та логічно виважені прийоми репрезентації інформації та тактики впливу на цільову аудиторію, які позбавляють масмедійні тексти монотонності та відрізняють їх від інших. Зафіксовано, що графічні символи використовують з декораційною метою або як ідентифікатори торгових марок. Стрілки виконують низку різноманітних функцій і слугують засобом посилання на сайт; переходу на наступну сторінку або посилання на інформацію в наступному номері; структурування інформації; підсилення семантики вербальних засобів що символізує рух вперед; ідентифікації початку статті або завершення цитати; дублікації семантики вербальних засобів із метою підсилення значення.

Ключові слова: масмедіа, комунікативний простір, діакритичні знаки, типографічні знаки, функція.

Вступ. Знаки пунктуації не належать до англомовної алфавітної графічної системи, однак є важливими компонентами комунікації. Це окрема система знаків, які, як свідчить проведений аналіз, можуть функціонувати самостійно, не будучи залученими до симбіозу різних систем. Знаки пунктуації, на котрі звертаємо увагу в розвідці, не лише виконують свою первинну функцію, а й здебільшого виступають у зовсім іншій ролі, цілком відмінній від загальноприйнятих стандартів і норм. У традиційному уявленні вони - невід'ємні складники тексту, виражають емоційний стан мовця, показують паузи під час писемної інтеракції або закінчення думки.

Корпус фактичного матеріалу дає підстави стверджувати, що такі невербальні елементи сприяють тому, що англомовний масмедійний простір є мультимодальним. У зв'язку з цим особливої значущості набуває всебічне дослідження різних аспектів мультимодальності сучасного спілкування, дослідження яких здійснено в роботах вітчизняних і зарубіжних учених, зокрема Дж. Беземера [6], К. Джевіт [7], Г. Кресса [8], Т. ван Лівена [11], С. Норріс [9], К. О’Халлоран [10], В. А. Сфименко [3], М. А. Карп [4], О. В. Білецька [1], О. С. Маріна [5], Н. Я. Град [2].

Незважаючи на значну кількість розвідок щодо англомовної масмедійної мультимодальної царини, відкритим залишається питання про функційні, структурні та семантичні особливості знаків пунктуації як важливих поліесемантичних складників спілкування, що й зумовлює актуальність обраної проблематики.

Постановка мети та завдань. Мета роботи полягає у визначенні семантичного навантаження та ідентифікації функційного призначення знаків пунктуації як інтегральних компонентів масмедійного комунікативного простору й зумовлює потребу у виконанні таких завдань:

- здійснити вибірку ілюстративного матеріалу в англомовних періодичних виданнях;

- виокремити елементи різних груп загалом та компоненти, які входитимуть до групи «Непіктографічні та нефотографічні елементи» зокрема; 
- проаналізувати знаки пунктуації 3 урахуванням їх структури, семантики та функційного навантаження.

Методи та методики дослідження. Методика дослідження охоплює кілька взаємопов'язаних етапів. Так, на першому етапі шляхом використання методу суцільної вибірки сформовано корпус ілюстративного матеріалу. На другому етапі, спираючись на описовий метод та методи індукції, дедукції, аналізу й синтезу, проаналізовано виявлені засоби, здійснено інвентаризацію та систематизацію невербальних і паравербальних компонентів. На третьому етапі застосовано метод дистрибутивного аналізу, який уможливив формування найбільш частотних оточень невербальних та паравербальних компонентів, що функціонують в англомовному масмедійному комунікативному просторі. Четвертий етап зорієнтований на ідентифікацію функційного призначення й визначення ролей невербальних $\mathrm{i}$ паравербальних засобів із розкриттям їхніх значень, можливих сполучуваностей і врахуванням соціальних параметрів. На цьому етапі застосовано соціосеміотичний i системно-функційний методи. Використання геосеміотичного підходу на п'ятому етапі дало змогу докладно проаналізувати ілюстративні компоненти невербальної природи, виявивши їх взаємозв'язок та взаємозалежність із вербальними одиницями. В основу шостого етапу покладено порівняльний і контекстологічний методи, які уможливили ідентифікацію спільних та відмінних ознак невербальних і паравербальних компонентів та дали змогу з'ясувати значення аналізованих компонентів.

Результати та дискусії. В англомовному масмедійному комунікативному просторі важливу роль відграють діакритики (див. табл. 1). Діакритичні знаки - це надрядкові або підрядкові знаки біля букв, які вказують на вимову, що відрізняє їх 3-поміж звуків, позначених цими ж літерами без знаків [12].

Аналізуючи цей модус, зауважимо, що вони не характерні для англійської абетки, однак їх використовують у різноманітних джерелах, оскільки діакритики притаманні словам іншомовного походження. Вочевидь, вони «зберігають» свою графічну специфіку в мові-реципієнті, тому що часто позначають культуроспецифічні реалії етнічних груп. Такі лексеми досить швидко «адаптовуються» до англомовного середовища, більшість із них зафіксовані в лексикографічних джерелах і мають різні ступені асиміляції. Обгрунтуємо докладніше їхню специфіку.

Таблиия 1

Використання діакритичних знаків в англомовному масмедійному комунікативному просторі

\begin{tabular}{|c|c|c|}
\hline Назва & Знак & Приклад \\
\hline Акут & ' & $\begin{array}{l}\text { In } 1870 \text { Frédéric Bazille painted "African Woman with Peonies", an } \\
\text { intriguing picture for his sister-in-law, who gave birth in that very month. } \\
\text { Frédéric Bazille's "African Woman with Peonies" [33, c. 10]. } \\
\text { Nambé [32, c. 25]. } \\
\text { The outages, which affected the Eiffel Tower, train lines and even the } \\
\text { president's home, where orchestrated by France's far - left union, the } \\
\text { Confédération Générale du Travail, in response to ongoing parliamentary } \\
\text { plans to pravatize the country's energy sector [28, c. } 28] \text {. } \\
\text { "Of the mining companies here, only five make a full set of safety equipment } \\
\text { obligatory", says Andrés Paniura Quispe, a safety engineer who works with } \\
\text { one of the few companies that maintains high standards but still requires } \\
\text { miners to buy their own equipment [24, c. 26]. } \\
\text { É muito barato. Inscreva-se já no Plano Celular } 21 \text { Local Pós-pago [26, c. 26]. } \\
\text { Like Chrétien, Harper has been lucky with his opponents and ruthless in } \\
\text { pressing advantage [36, c. 21]. }\end{array}$ \\
\hline Гачок & $\checkmark$ & Chloe $[21$, c. 34]. \\
\hline Гравіс & r & $\begin{array}{l}\text { Andrea IIIy IIIycaffe } \text { [31, c. 26]. } \\
\text { Monet surely wanted to represent dahlias of which he was especially proud, } \\
\text { some of them very much ‘ a la mode [33, c. } 28] \text {. }\end{array}$ \\
\hline
\end{tabular}




\begin{tabular}{|c|c|c|}
\hline $\begin{array}{c}\text { Літера лат. } \\
\text { абетки }\end{array}$ & ç & $\begin{array}{l}\text { An Ottoman Traveller: Selections from the Book of Travels of Evliya çelebi } \\
\text { Edited by Robert Dankoff and Sooyong Kim }[17, \text { c. 36]. }\end{array}$ \\
\hline Макрон & - & Ihe new palm prè \\
\hline Тильда & $\sim$ & $\begin{array}{l}\text { Com o } 21 \text {, voc^e liga pelo cecular a qualquer hora para qualquer lugar do } \\
\text { mundo a preço de ligação local }[25, \text { c. } 46] \text {. }\end{array}$ \\
\hline $\begin{array}{l}\text { Циркумфл } \\
\text { екс }\end{array}$ & $\wedge$ & $\begin{array}{l}\text { Com o } 21 \text {, voc^e liga pelo cecular a qualquer hora para qualquer lugar do } \\
\text { mundo a preço de ligação local [25, c. 22]. }\end{array}$ \\
\hline $\begin{array}{l}\text { Умляут } \\
\text { (діарезис) }\end{array}$ & .. & $\begin{array}{l}\text { Löw revels in tactics that tore up England defence [30, c. 23]. } \\
\text { Jörh Haider [37, c. 31]. Möben [37, c. 23]. }\end{array}$ \\
\hline Апостроф & , & $\begin{array}{l}\text { The same is true of the shocks of ' } 86 \text { and '91; they were passing events } \\
{[28, \text { c. 11]. }}\end{array}$ \\
\hline
\end{tabular}

На шпальтах англомовної періодики трапляються також математичні символи в невластивій для них ролі. Традиційно знак дорівнює показує рівність або кінцеву відповідь у випадку необхідності знаходження невідомого під час розв'язання завдань із фізики, хімії чи математики.

У масмедіа він іноді слугує засобом рівності, ототожнюючи слова, а, відтак, і їхню семантику (рис. 1, 3). Books = Gifts; NEW YEAR = NEW BENEFITS. Такі мультимодальні рівності розкривають багатогранні можливості. Порівнюючи математичні та мовні протиставлення, можемо стверджувати, що якщо перші ідентичні, то значення других змушує читача замислитися над продукцією, або ж пропозиціями, що на нього чекають. У першому випадку додаткового дешифрування немає, у другому воно частково представлене, але докладну інформацію не подано.

На рис. 2 додаток газети The Times (Times+) містить позначку арифметичного символу +. Таке представлення видання має традиційний характер. Упродовж років аналізований символ став диференційною ознакою видання. У цьому випадку йдеться про статус ідентифікатора додатка газети The Times.

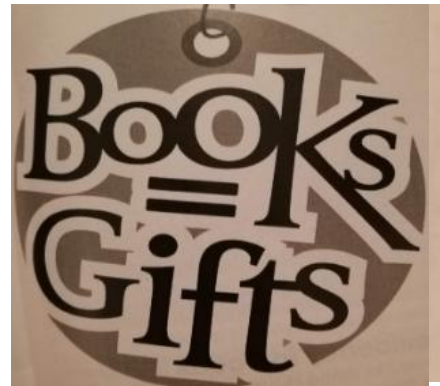

Рис. 1. [23, с. 151]

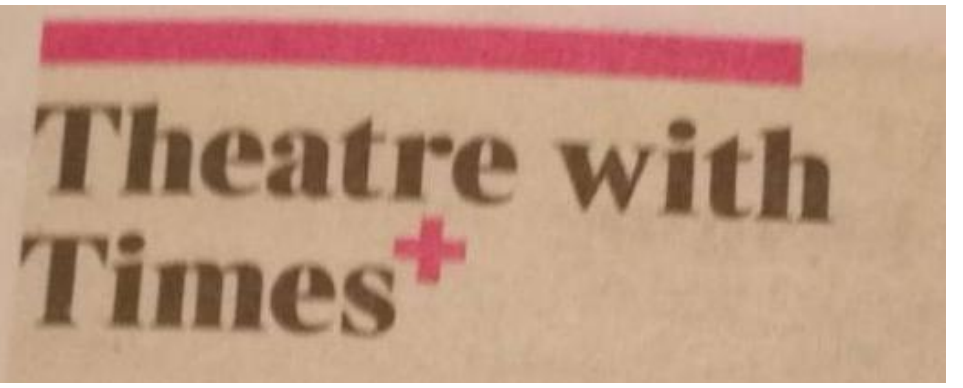

Рис. 2. [39, с. 13]

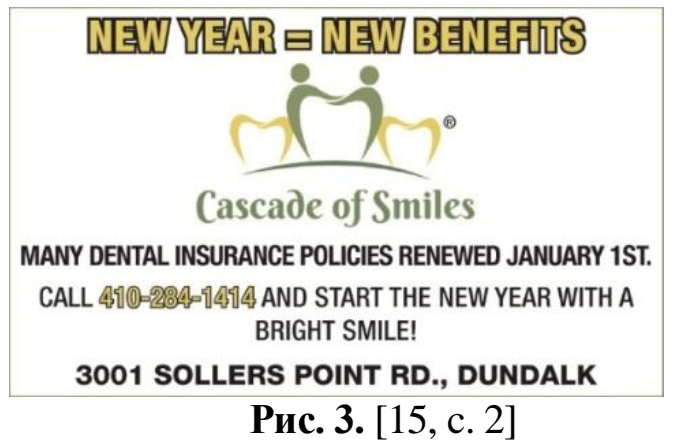

В англомовному масмедійному комунікативному просторі, окрім тих ресурсів, які представлено й схарактеризовано вище, послуговуються також. Зауважимо, що, наприклад, знак@є поліфункційним, оскільки може слугувати замінником at, зрідка and, а також (як бачимо на рис. 4) графеми $a$. Цей знак - не частина кодифікованих вербальних позначок, не належить до знаків пунктуації, а є допоміжним ресурсом. На рис. 5 зображено три знаки, які 
мають зацікавити читача. Це позначка номера \#, символ, що позначає американську валюту \$ та зірочка, яку використовують як зноску*. Вони виконують традиційні функції. Наприклад, останній знак свідчить, що внизу сторінки розміщена додаткова інформація щодо рекламованого продукту.

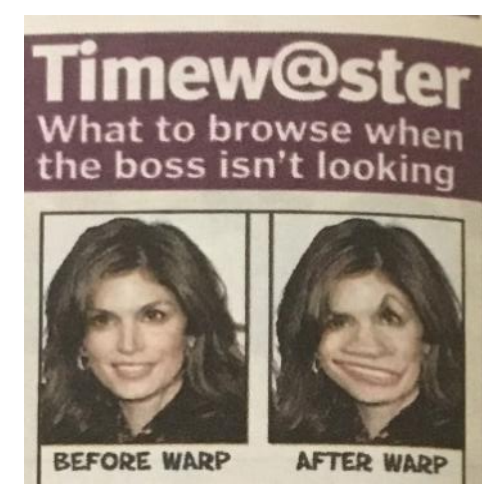

Рис. 4. [22, с. 14]

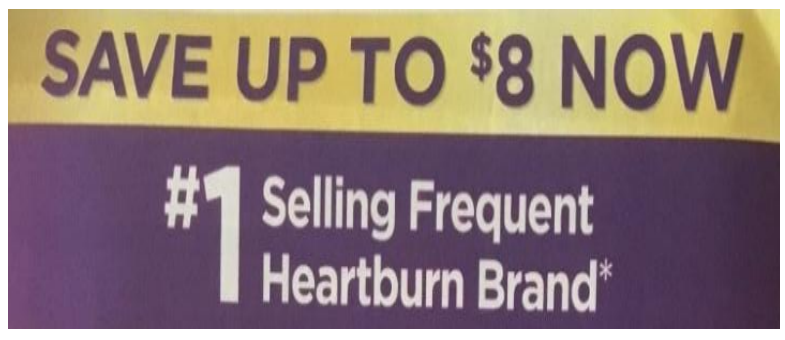

Рис. 5. [14]

Подібне використання різноманітних типографічних позначок або додаткових графічних символів, використаних із декораційною метою або як елементів торгової марки чи фірмового стилю, простежено на рис. 6-9. Наприклад, на рис. 9 зірки слугують субституційними елементами знаків пунктуації. Водночас, вони є засобами компресії, оскільки уникають деталей та грунтовного опису. Такий спосіб викладу матеріалу лаконічний, оскільки йдеться про використання критерію мовної економії. Графічні засоби сприяють іiї реалізації.

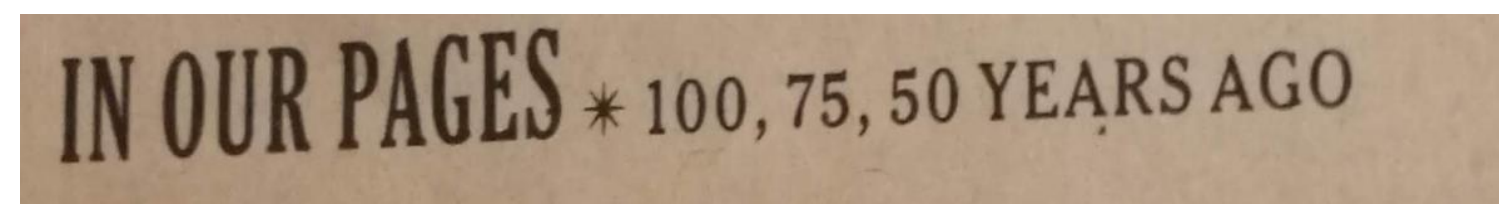

Рис. 6. [21, c.2]

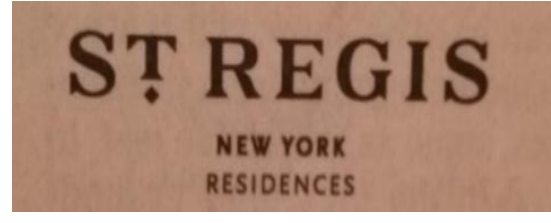

Рис. 7. [19, с. 10]

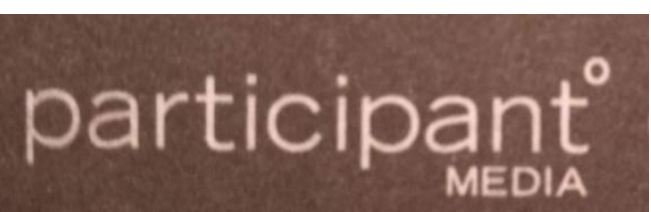

Рис. 8. [33, c. 17]

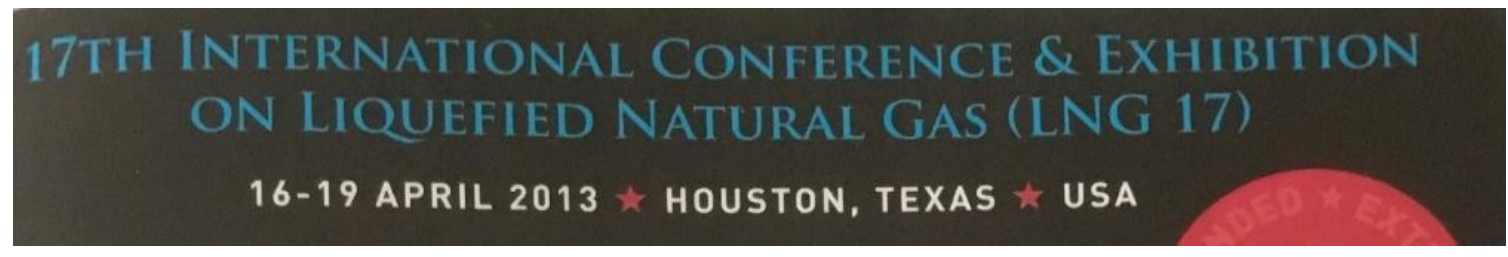

Рис. 9 [38, с. 52]

На рис. 10 у рекламі міжнародної школи менеджменту використано низку квадратів. Їхня мета - лаконічно представити специфіку запропонованих освітніх програм. У цьому випадку можна стверджувати, що квадрати є засобом структурування інформації та тим елементом, що скомпресовано представляє іiі, тобто реалізовує критерії мовної компресії.

У рекламному блоці на рис. 11 спостережено використання кількох «пташечок» та «хрестик». Традиційно «пташечками» послуговуються тоді, коли відповідь є позитивною (правильною / так), «хрестиками» - коли відповідь негативна (неправильна / ні). Продуценти таким способом закликають потенційних користувачів виконувати або не виконувати певні дії, споживаючи запропонований товар. 


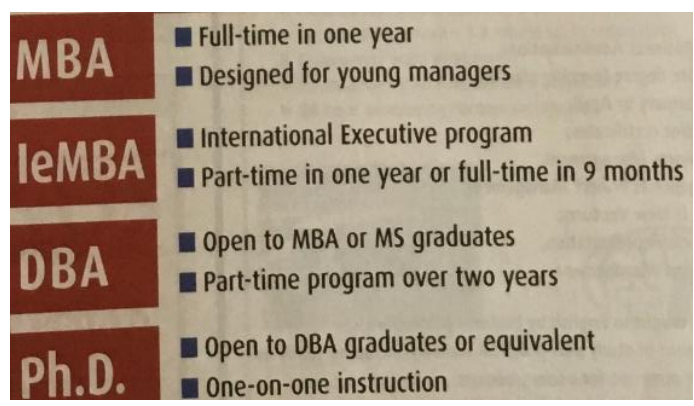

Рис. 10. [35, c.81]

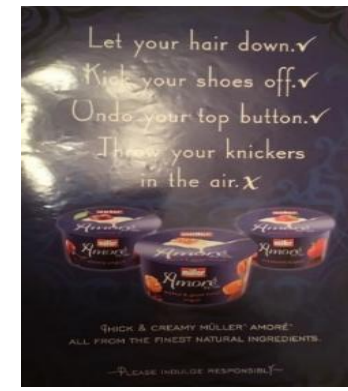

Рис. 11. [20, с.128]

У масмедійному комунікативному просторі фіксуємо широкий спектр стрілок, які використовують як засіб:

- посилання на сайт як додаткове джерело інформації (рис. 12, 13);

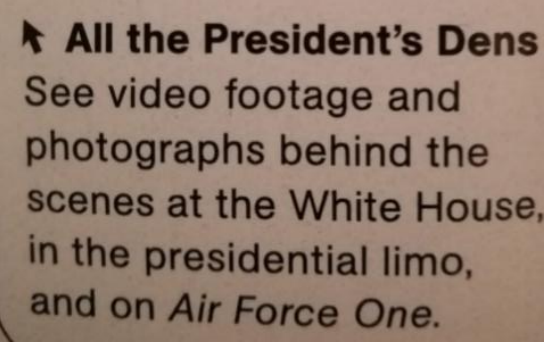

Рис. 12. [23, с. 4]

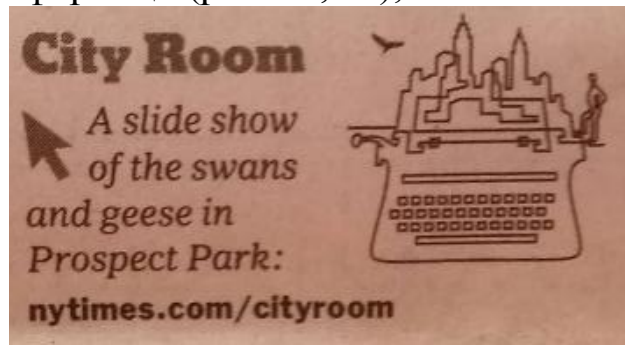

Pис. 13 [32, с. A24]

- переходу на наступну сторінку або посилання на інформацію в наступному номері (рис. 14);

- структурування інформації (рис. 15);

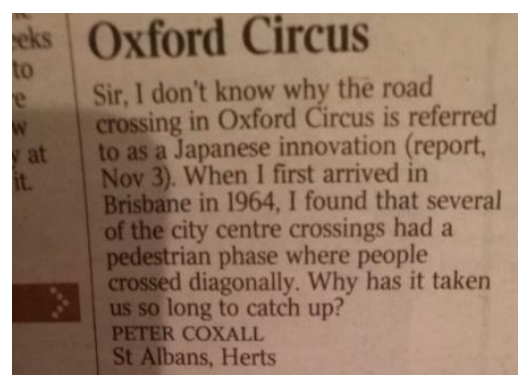

Рис. 14. [34, с. 38]

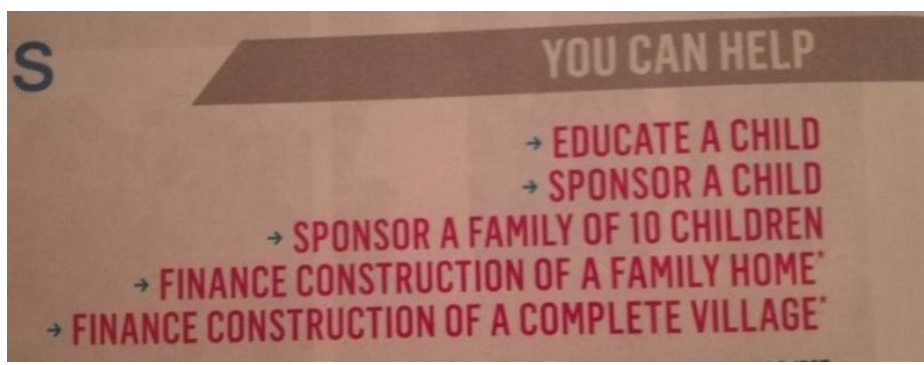

Рис. 15. [25, с. 15]

- підсилення семантики вербальних засобів що символізує рух вперед (рис. 16);

- ідентифікації початку статті (рис. 17);

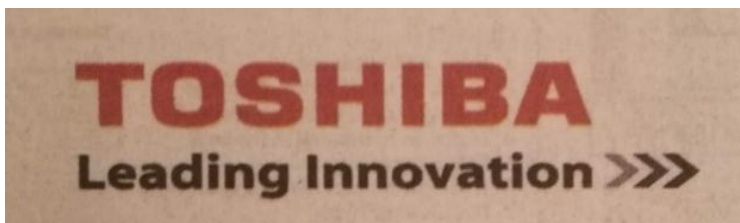

Рис. 16. [25, с. 10]

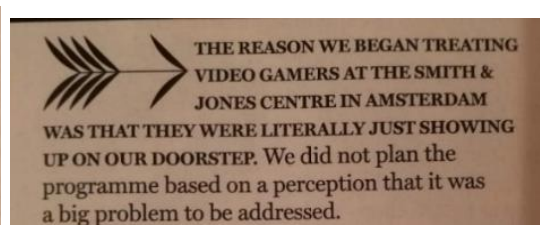

Рис. 17. [18, с. 7]

- ідентифікації завершення цитати (рис. 18);

- дублікації семантики вербальних засобів із метою підсилення значення (рис. 19).

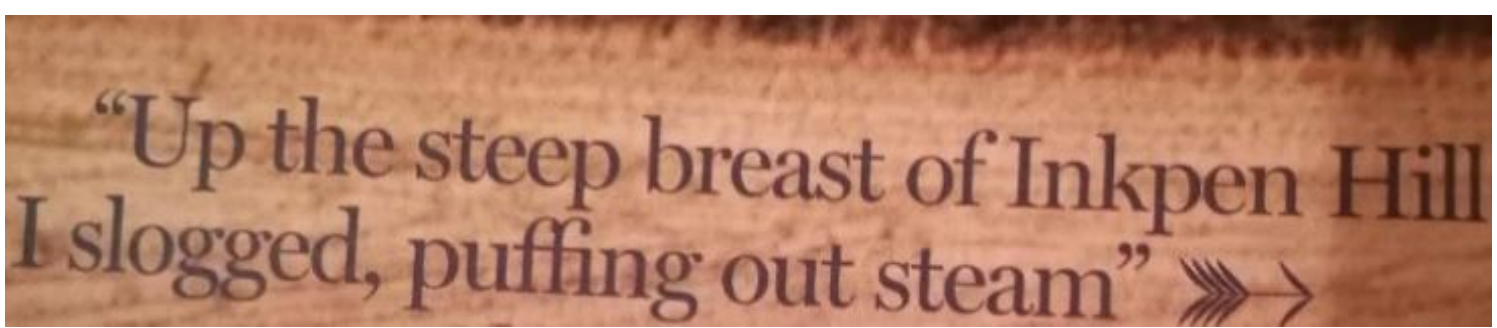

Рис. 18. [18, с. 37] 
Амперсанд (\&), використаний у назві журналу «Accounting \& Business», упродовж тривалого часу $є$ невід'ємним компонентом назви (21). Його часто використовують як компресивний компонент на позначення лексеми and. Крім перелічених та охарактеризованих вище компонентів, зафіксовано й інші (рис. 20). Скажімо, схематична позначка руки є засобом стуктурування інформації в певній рубриці, сигналізує про початок частини тексту та $\epsilon$ відправною точкою, яка розпочинає певний абзац або текст.

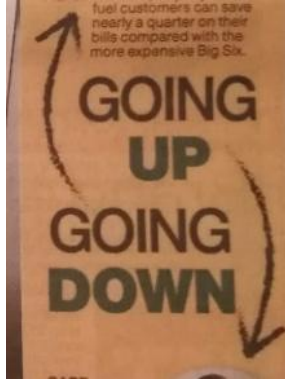

Рис. 19. $[33$, с. 31]

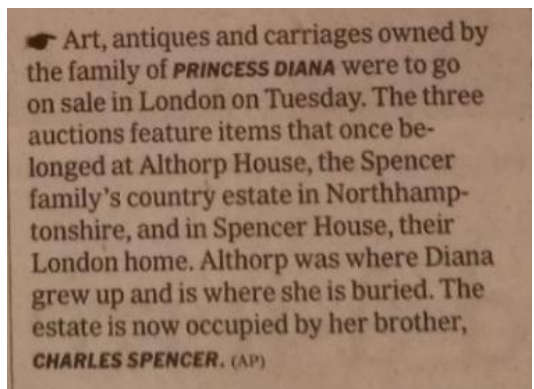

Рис. 20. [13, с. 1]

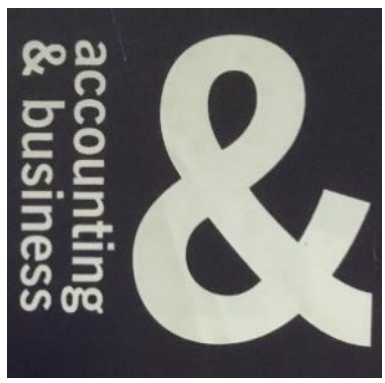

Рис. 21. [16, с. 34]

\section{Acquire Fees (a) $<50 \%$ GRAF}

Рис. 22. [13, с. 85]

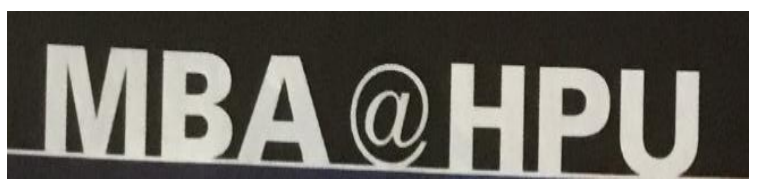

Pис. 23. [3, с. 56]

На рис. 22 представлено невербальне скорочення, вжите в реченні @ < 50 \%. До його продукування залучено скорочення @, арифметичні знаки й цифри. Воно досить складне, а тому дешифрувати його зміст допомагає контекст. Рис. 23 демонструє поєднання абревіатур та скорочення @. Комбінації такого типу найпоширеніші в англомовному масмедійному комунікативному просторі.

Висновки. Усі охарактеризовані непіктографічні та нефотографічні елементи (діакритичні знаки, типографічні й інші допоміжні знаки, математичні символи абревіатури, що поєднують лише невербальні одиниці чи вербальні й невербальні компоненти, одночасно $\epsilon$ важливими складниками сучасного англомовного масмедійного комунікативного простору. Проаналізовані вище фрагменти доводять їх поліфункційний характер та свідчать про те, що їхні можливості необмежені.

Перспективними видаються подальші розвідки, спрямовані на дослідження непіктографічних та нефотографічних компонентів, якими послуговуються в англомовному масмедійному комунікативному просторі і які виконують атипові ролі.

\section{References}

1. Biletska, Olena. 2014. "Hrafichna forma postmodernistskoho khudozhnoho tekstu kriz pryzmu hrafichnoi linhvistyky". Nova filolohiia 60: 17-22.

2. Hrad, Nataliia. 2014. "Suchasni multymodalni studii: modalna linhvistyka ta multymodalna stylistyka". Odeskyi linhvistychnyi visnyk 4: 49-51. URL: http://nbuv.gov.ua/UJRN/olinv_2014_4_15 (data zvernennia: 13.11.2017).

3. Yefymenko, Viktoriia. 2013. "Intertekstualni zviazky mizh tekstovymy svitamy kazkovykh tvoriv". Studia linguistica 7: 322-326.

4. Karp, Marta. 2016. "Vzaiemodiia zasobiv kontaminovanoi leksychnoi kohezii v teksti anhliiskykh multymodalnykh literaturnykh kazok Filipa Arda". Naukovi zapysky Natsionalnoho universytetu "Ostrozka akademiia”. Seriia: Filolohiia 62: 136-139.

5. Marina, Olena. 2015. Semiotyka paradoksalnosti u kohnityvnokomunikatyvnomu vysvitlenni (na materiali suchasnoho anhlomovnoho poetychnoho dyskursu) : monohrafiia. Kherson: Ailant.

6. Bezemer, Jeff. 2014. Multimodal Transcription: a Case Study. Interactions, Images and Texts: a Reader in Multimodality. Berlin : De Gruyter Mouton, 155-170.

7. Jewitt, Carey. 2008. "Multimodal Classroom Research". AERA Review of Research in Education 32: 241-267.

8. Kress, Gunther. 2003. Literacy in the New Media Age. London; New York: Routledge.

9. Norris, Sirgid. 2009. "Modal Density and Modal Configurations: Multimodal Actions". The Routledge Handbook of Multimodal Analysis / ed. by C. Jewitt. London; New York: Routledge, 78-91. 
10. O’Halloran, Kay. L. 2014. Multimodal Studies: Exploring Issues and Domains (Routledge Studies in Multimodality). 1st ed., 1-41.

11. Van Leeuwen, Theo. 2004. Introducing Social Semiotics. London: Routledge.

12. Діакритичний знак. 2014. URL: https://uk.wikipedia.org/wiki/Діакритичний знак (дата звернення: 02.09.2014)

\section{Sources of Exemplifying Material}

13. Accounting \& Business. 2007. No. 6. Vol. 10. June.

14. Advertising Leaflet. 2017. URL: http://www. hongkiat.com/blog/creative (дата звернення: 19.08.2018).

15. Community News. 2016. June, 23.

16. Financial Times. 2009. No. 27, 657. June, 6-7.

17. Financial Times. 2009. No. 37, 136. Tuesday, October, 20.

18. FT Weekend Magazine. 2008. No. 288. December, 20-21.

19. FT Weekend. 2010. No. 37436. Saturday/Sunday, October, 9-10.

20. Hello! 2009. No. 1085. August, 17.

21. International Herald Tribune. 2009. No. 39, 173. Thursday, February, 19.

22. London Lite. 2007. Wednesday, May, 9.

23. National Geographic. 2009. No. 1. Vol. 215. January.

24. National Geographic. 2009. No. 6. Vol. 215. June.

25. Newsweek. 2004. No. 10. September, 6-13.

26. Newsweek. 2004. No. 13. March, 29.

27. Newsweek. 2004. No. 21. May, 24.

28. Newsweek. 2004. No. 26. June, 28.

29. The Daily Telegraph. 2009. No 48, 054. Tuesday, December, 1.

30. The Independent. 2010. No. 7, 397. Monday, June, 28.

31. The New York Times. 2009. No. 54, 626. Thursday, March, 26.

32. The New York Times. 2010. No. 55, 051. Tuesday, May, 25.

33. The Sun. 2018. Thursday, May, 10.

34. The Times. 2008. No. 69 493. Friday, November, 28.

35. Time. 2003. No. 7. Vol. 162. August, 18-25.

36. Time. 2009. No. 6. Vol. 173. February, 9.

37. Time. 2009. No.11. Vol. 174. September, 21.

38. Time. 2013. No. 12. Vol. 181. April, 1.

39. USA Today. 2008. No. 5137. Thursday, November, 11.

Макарук Лариса. Функционирование диакритических, математических и типографических знаков в современном англоязычном коммуникативном пространстве. В статье исследовано невербальные и паравербальные ресурсы, которые функционируют в современном англоязычном массмедийном коммуникативном пространстве. Проанализировано диакритические, математические и типографические знаки как невербальные элементы, являющиеся составляющими одной из групп, которые в целом охватывают невербальные и паравербальные компоненты, которые функционируют в современном англоязычном массмедийном коммуникативном пространстве. К рассматриваемой группе «Непиктографические и нефотографические элементы» входят знаки препинания; диакритические знаки; типографические и другие вспомогательные знаки; цифры (числа) математические символы; аббревиатуры.

В этом исследовании подробно освещена специфика диакритических, математических и типографских знаков как интегральных модусов массмедийной среды. Определены их семантические и структурные особенности, идентифицированы функциональные нагрузки, обоснованно их роль и назначение в современном англоязычном массмедийном коммуникативном пространстве. Кроме традиционного использования, диакритическим, математическим и типографским знакам также присуще и нетрадиционное. Установлено, что в массмедийном пространстве спектр потенциальных возможностей диакритических, математических и типографических знаков значительно шире, что и доказывает их полифункционный характер.

Диакритики рядом со знаками препинания часто имеют значение, выходящее за рамки их традиционного назначения. Такие комбинации не случайны, это тщательно продуманные и логически обоснованные приемы репрезентации информации и тактики воздействия на целевую аудиторию, которые лишают массмедийные тексты монотонности и отличают их от других. Зафиксировано, что графические символы используют с декорационной целью или как идентификаторы торговых марок. Стрелки выполняют ряд различных функций и служат средством ссылки на сайт; перехода на следующую страницу или ссылки на информацию в следующем номере; структурирования информации; усиления семантики вербальных средств, символизирующее движение вперед; идентификации начала статьи или завершения цитаты; дубликации семантики вербальных средств с целью усиления значения.

Ключевые слова: масс-медиа, коммуникативное пространство, диакритические знаки, типографические знаки, функция. 
Makaruk Larysa. The Functioning of Diacritical, Mathematical and Typographical Symbols in the Modern English Mass Media Communicative Space. This article is focused on the investigation of non-verbal and paraverbal resources which are utilized in the modern English-language mass media communicative space. In this paper, an analysis of diacritical, mathematical and typographical symbols is presented when their utilization places them within the general category of non-verbal and paraverbal elements in the modern English-language mass media communicative space. The group "Non-pictographical and non-photographic elements" includes punctuation marks, as well as diacritical, typographic and other auxiliary signs, and mathematical symbols, and abbreviations. As noted above, this study focuses in detail on the specific features of various types of diacritical, mathematical and typographical marks as integral modes within the media environment.

Their semantic and structural features are outlined, their functional load is identified, and their role in the modern English-language mass media communicative space are demonstrated. In addition to their traditional use they are also used unconventionally. It has been established that diacritical, mathematical and typographical marks have a broader range of possibilities and multifunctional potential. Diacritical and punctuation marks often have a meaning which proves their irregular usage. It has been shown that these combinations are not inadvertent, but on the contrary, are well thought and logical techniques for presenting information and influencing potential audiences. It has been demonstrated that these graphic symbols are used for decorations and they often serve as trademarks.

Arrows perform a number of different functions and serve as a means of directing attention from a text reference to a pertinent URL; to direct attention to a subsequent page or a subsequent issue of a periodical; to perform a specific pointing function, in order to direct the attention of readers to an image or potentially to a text box which is referred to within the body of an article; to indicate the item structure of information, in the same manner as bullet points; to visually reinforce a textual reference to literal or figurative movement in a vertical or horizontal direction; to perform a specific pointing function, in order to direct the attention of readers to an image or potentially to a text box which is referred to in an article; to duplicate the meaning given in a text.

Key words: mass media, communicative space, diacritical marks, typographical marks, function.

DOI: https://doi.org/10.32782/2410-0927-2020-13-19

УДК 81'27’373.43'42:004.439]:37.018.43

Леся Малімон, Діана Лепка

\section{ХЕШТЕГИ НА ПОЗНАЧЕННЯ ДИСТАНЦЙНОГО НАВЧАННЯ: ЛЕКСИКО- СЕМАНТИЧНИЙ ТА ФУНКЦОНАЛЬНИЙ АСПЕКТИ}

У статті визначено основні лексико-семантичні та функціональні особливості хештегів як нових засобів взаємодії в медіапросторі. Виокремлено основні типи медіадискурсу, особливості інтернет-дискурсу й причини передачі інформації в ньому різними полікодовими системами. Вивчено феномен «хештегів», визначено історичні передумови виникнення цього явища в дописах Інтернет-користувачів та ідентифіковано основні функції хештегів у соціальних мережах. Проведено дослідження нових хештегів на позначення дистанційного навчання. Визначено основні тенденції в медіапросторі у 2020 р. пов'язані з лексико-семантичними особливостями хештегів. Відповідно до принципів квалітативного методу, здійснено відбір хештегів про дистанційне навчання, а індуктивний метод дав змогу прокласифікувати релевантний фактичний матеріал. Згідно 3 методами теоретичного узагальнення, групування й порівняння виконано багатоаспектний аналіз хештегів на позначення дистанційного навчання.

Проведено цілісний аналіз системи нових хештегів на позначення дистанційного навчання, що виникли у 2020 р. Аналіз цих елементів медіапростору дав змогу виокремити хештеги, що виражають суб'єктивне ставлення користувачів до феномену «Distance Learning»; хештеги, що виконують попередньо класифікаційну функцію; комплекс хештегів, що не мають прагматичного компонента значення; хештеги, що тематично маркують дописи; frame-building hashtags; dissemination hashtags. Визначено групи комерційних хештегів, котрі використовують не лише в приватних публікаціях. Ідентифіковано різноманітні функції хещтегів на позначення дистанційного навчання, до яких належать категоризація, попередньо-класифікаційна та характеризуюча функції, репрезентативна функція, кореферентна функція. Розкрито особливості ідейного змісту хештегів, що не мають прямого зв'язку з онлайн-освітою, а $є$ лише дотичними до теми навчання. Хоча такі хештеги не $\epsilon$ семантично пов'язані зі змістом дописів інтернеткористувачів, їх часто поєднують з різними комплексами хештегів для досягнення цільової аудиторії.

Ключові слова: хештег, лексико-семантичні особливості, медіалінгвістика, медіадискурс, інтернет-дискурс, дистанційне навчанння.

Вступ. Безперервність технологічного прогресу сприяє постійній зміні каналів передачі інформації та, отже, методів комунікації в соціумі. Проте, незважаючи на загальне розуміння нових тенденцій, і досі складно окреслити всі наслідки диджиталізації медіапростору та безперервного використання медіатехнологій користувачами. Зміна принципів взаємодії в

(С) Малімон Л., Лепка Д., 2020 